\title{
Warming increases carbon and nutrient fluxes from sediments in streams across land use
}

\author{
S.-W. Duan and S. S. Kaushal \\ Department of Geology and Earth System Science Interdisciplinary Center, University of Maryland, College Park, \\ Maryland, 20742, USA
}

Correspondence to: S.-W. Duan (sduan@umd.edu)

Received: 22 July 2012 - Published in Biogeosciences Discuss.: 22 August 2012

Revised: 25 December 2012 - Accepted: 10 January 2013 - Published: 25 February 2013

\begin{abstract}
Rising water temperatures due to climate and land use change can accelerate biogeochemical fluxes from sediments to streams. We investigated impacts of increased streamwater temperatures on sediment fluxes of dissolved organic carbon (DOC), nitrate, soluble reactive phosphorus (SRP) and sulfate. Experiments were conducted at 8 long-term monitoring sites across land use (forest, agricultural, suburban, and urban) at the Baltimore Ecosystem Study Long-Term Ecological Research (LTER) site in the Chesapeake Bay watershed. Over $20 \mathrm{yr}$ of routine water temperature data showed substantial variation across seasons and years. Lab incubations of sediment and overlying water were conducted at 4 temperatures $\left(4^{\circ} \mathrm{C}, 15^{\circ} \mathrm{C}, 25^{\circ} \mathrm{C}\right.$, and $35^{\circ} \mathrm{C}$ ) for $48 \mathrm{~h}$. Results indicated: (1) warming significantly increased sediment DOC fluxes to overlying water across land use but decreased DOC quality via increases in the humic-like to protein-like fractions, (2) warming consistently increased SRP fluxes from sediments to overlying water across land use, (3) warming increased sulfate fluxes from sediments to overlying water at rural/suburban sites but decreased sulfate fluxes at some urban sites likely due to sulfate reduction, and (4) nitrate fluxes showed an increasing trend with temperature at some forest and urban sites but with larger variability than SRP. Sediment fluxes of nitrate, SRP and sulfate were strongly related to watershed urbanization and organic matter content. Using relationships of sediment fluxes with temperature, we estimate a $5{ }^{\circ} \mathrm{C}$ warming would increase mean sediment fluxes of SRP, DOC and nitrate- $\mathrm{N}$ across streams by $0.27-1.37 \mathrm{~g} \mathrm{~m}^{-2} \mathrm{yr}^{-1}, 0.03$ $0.14 \mathrm{~kg} \mathrm{~m}^{-2} \mathrm{yr}^{-1}$, and $0.001-0.06 \mathrm{~kg} \mathrm{~m}^{-2} \mathrm{yr}^{-1}$. Understanding warming impacts on coupled biogeochemical cycles in streams (e.g., organic matter mineralization, P sorption, nitri-
\end{abstract}

fication, denitrification, and sulfate reduction) is critical for forecasting shifts in carbon and nutrient loads in response to interactive impacts of climate and land use change.

\section{Introduction}

An improved understanding of coupled biogeochemical cycles is warranted in forecasting the interactive effects of climate and land use change on water quality in streams and rivers (Chapin III et al., 2011; Howarth et al., 2011; Schlesinger et al., 2011). In particular, the transformations of bioreactive elements (carbon, nitrogen, phosphorus and sulfur) represent important processes for regulating biogeochemical cycles and water quality (Froelich, 1988; Seitzinger, 1988; Daila and Fitzgeraldb, 1999; Battin et al., 2008). The role of sediments is particularly critical in small streams compared with larger rivers due to the greater potential for hydrologic interactions between surface water with sediments in response to channel morphology/geometry and hyporheic exchange (e.g., Alexandria et al., 2000). Stream sediments can act as "sources" or "sinks" of bioreactive elements, where they can be either transferred from the water column to sediments through abiotic adsorption and biotic uptake (Bowes et al., 2003; Arango et al., 2008; Kaplan et al., 2008) or released back to the water column via diffusing diagenetic products of organic matter decomposition or reduction reactions (Jensen and Andersen, 1992; Aguilar and Thibodeaux, 2005).

Transformations of organic carbon, nitrogen, phosphorus and sulfur differ but are linked in sedimentary diagenesis near the water-sediment interface. Nitrate, soluble reactive phosphorus (SRP) and sulfate may release along with 
dissolved organic carbon (DOC) as a result of leaching and oxidization of sedimentary organic matter. Meanwhile, as sediment organic carbon decomposition intensifies and dissolved oxygen (DO) is depleted, nitrate, iron/manganese hydroxides $\left(\mathrm{MnO}_{2} / \mathrm{Fe}_{2} \mathrm{O}_{3}\right)$ and sulfate sequentially act as the dominant electron acceptors (e.g., Middelburg and Levin, 2009). SRP that is adsorbed onto $\mathrm{MnO}_{2} / \mathrm{Fe}_{2} \mathrm{O}_{3}$ surfaces typically releases to stream water, as more $\mathrm{MnO}_{2}$ and $\mathrm{Fe}_{2} \mathrm{O}_{3}$ are reduced. As a result, bioreactive elements can cycle differently and undergo release or retention from sediments in response to shifting redox conditions and warming.

Temperature is an important variable influencing carbon, nitrogen, phosphorus and sulfur biogeochemical cycles in aquatic environments (House and Denison, 2002; Gudasz et al., 2010). Water temperature varies considerably with season in most streams and rivers globally, and there have been long-term warming water temperatures in streams and rivers due to interactive effects of climate and land use change (e.g., Webb and Nobilis, 2007; Kaushal et al., 2010). In addition, there can be surges and increased variability in stream water temperatures due to urban runoff from impervious surfaces (Kim, 2007; Nelson and Palmer, 2007; Kaushal et al., 2010). Because decomposition of sedimentary organic matter is a process that can be stimulated by warming (White et al., 1991; Arnosti et al., 1998; Gudasz et al., 2010), biogeochemical fluxes from sediment may be enhanced at higher water temperatures and result in altered fluxes of SRP, sulfate, and nitrate in response to warming. Simultaneously, urbanization has been shown to increase levels of labile organic matter, nutrients, sulfate concentrations in streams and sediments (O'Driscoll et al., 2010 and references within). Therefore, increased water temperatures coupled with increased availability of carbon and nutrient sources can increase microbial activity in stream sediments (Imberger et al., 2008), and accelerate transformations of bioreactive elements.

Prior studies have commonly investigated the effects of warming on sediment fluxes and transformations of individual bioreactive elements, but little work has been done to improve our conceptual understanding of the interactive effects of land use and temperature on coupled biogeochemical cycles. The primary objective of the present study was to investigate the effects of land use and potential climate change on fluxes of bioreactive elements and organic carbon quality influenced by stream sediments. We tested two hypotheses: (1) warmer temperatures in stream water sequentially accelerate sediment transformations and fluxes of dissolved organic carbon (DOC), nitrate, soluble reactive phosphorus (SRP), and sulfate as a result of organic matter decomposition and, (2) sediment fluxes in urban watersheds are more sensitive to warming than rural watersheds. An improved understanding of the potential role of warming on fluxes of bioreactive elements in small streams and across the broader urban watershed continuum can contribute to our understanding of drivers of change in water quality, microbial communities, and ecosystem functions (Kaushal et al., 2010; Kaushal and Belt, 2012). It can also inform approaches for predicting alterations in the dynamics and fluxes of limiting nutrients in aquatic ecosystems and assessing potential impacts on downstream eutrophication in response to interactive climate and land use change.

\section{Methods}

\subsection{Site description}

Temperature-manipulation incubation experiments were conducted with stream sediments across 8 sites with varying land use (e.g., forest, agricultural, suburban and urban) at the US National Science Foundation supported Baltimore Ecosystem Study (BES) Long-term Ecological Research (LTER). The results of lab experiments were used to estimate annual sediment fluxes and predict changes in sediment fluxes with $5{ }^{\circ} \mathrm{C}$ warming. The BES LTER site in the Chesapeake Bay watershed provides access to extensive background information and long-term monitoring of nitrogen, phosphorus, sulfate, and carbon concentrations and fluxes in streams (www.beslter.org) (e.g., Groffman et al., 2004; Kaushal et al., 2008a, b, 2011). Long-term streamwater chemistry has been described extensively elsewhere (Groffman et al., 2004; Kaushal et al., 2005, 2008a, 2011; Duan et al., 2012).

Briefly, the main focal watershed of the BES LTER site is the Gwynns Falls, a 17150 ha watershed in the Piedmont physiographic province that drains into the northwest branch of the Patapsco River that flows into the Chesapeake Bay (Fig. 1). The Gwynns Falls sites traverse a rural/suburban to urban gradient from Glyndon (GFGL), Gwynnbrook (GFGB), Villa Nova (GFVN) to Carroll Park (GFCP) (Fig. 1 and Table 1). The stream near McDonogh School (MCDN) is a small tributary to the Gwynns Falls draining a watershed dominated by row crop agriculture (corn, soybeans), while Dead Run (DRKR) is an urbanized tributary of the Gwynns Falls between GFVN and GFCP. Samples were also taken from a small urban tributary to the Gwynns Falls (GFGR), approximately $700 \mathrm{~m}$ above GFCP, which was highly contaminated with sewage. Pond Branch (POBR) is a small reference forested watershed located in the nearby Gunpowder Falls watershed.

Long-term water temperature data from the Gwynns Falls at Villa Nova (GFVN) were acquired from the Chesapeake Bay Program (CBP) which is a co-operative effort between the US federal government and state and local governments in the Chesapeake Bay watershed. The station was sampled once a month from 1986-2006 and was used to characterize long-term temperature variability for the Gwynns Falls at the Baltimore LTER site. The records show a strong seasonal signal with highest values in July-August and lowest in January-February, although the long-term trends of annual mean, maximal and minimal temperature were not significant ( $p>0.05$ for linear or nonlinear regressions) during this 20-yr period (Fig. 2). 
Table 1. Characteristics of study subwatersheds.Watershed land cover and impervious surface (ISC \%) data are from Shields et al. (2008) and the National Land Cover Database (NLCD). Both land cover and impervious statistics were based on 30-m resolution land cover data.

\begin{tabular}{lcccccccc}
\hline Site & $\begin{array}{c}\text { POBR } \\
\text { forest }\end{array}$ & $\begin{array}{c}\text { MCDN } \\
\text { agriculture }\end{array}$ & $\begin{array}{c}\text { GFGB } \\
\text { suburban }\end{array}$ & $\begin{array}{c}\text { GFGL } \\
\text { suburban }\end{array}$ & $\begin{array}{c}\text { GFVN } \\
\text { urban }\end{array}$ & $\begin{array}{c}\text { GFCP } \\
\text { urban }\end{array}$ & $\begin{array}{c}\text { DRKR } \\
\text { urban }\end{array}$ & $\begin{array}{c}\text { GFGR } \\
\text { urban }\end{array}$ \\
Area (ha) & 0.4 & 0.1 & 11 & 0.8 & 84.2 & 170.7 & 14.3 & 6.5 \\
\% ISC & 0 & 0.1 & 15 & 19 & 17 & 24 & 45 & 61 \\
\hline Developed/open & & 13.6 & 43.8 & 41.2 & 27.4 & 25.5 & 22.4 & 9.2 \\
Developed/low & & 5.4 & 28.9 & 21.5 & 25.2 & 28.8 & 38.8 & 27.5 \\
Developed/medium & & 3.6 & 4.3 & 8.3 & 10.5 & 16.2 & 18.1 & 43.6 \\
Developed/high & & & 1.3 & 3.4 & 2.5 & 5.0 & 7.4 & 17.4 \\
Barren & & & & & 0.2 & 0.1 & 0.1 & 0.04 \\
Shrub & 1.3 & 7.9 & 1.1 & 6.3 & 1.4 & 0.8 & 0.2 & 0.05 \\
Forest & 98.7 & 1.4 & 19.0 & 19.2 & 25.5 & 19.3 & 12.7 & 1.3 \\
Hay/pasture & & 30.4 & 0.9 & 0.1 & 3.1 & 1.7 & 0.1 & \\
Cultivated crops & & 37.1 & 0.1 & & 3.4 & 1.8 & & 0.2 \\
Wetland & & 0.7 & 0.6 & & 0.8 & 0.7 & 0.2 & \\
Open water & & & & & 0.1 & 0.1 & & 0.9 \\
\hline
\end{tabular}
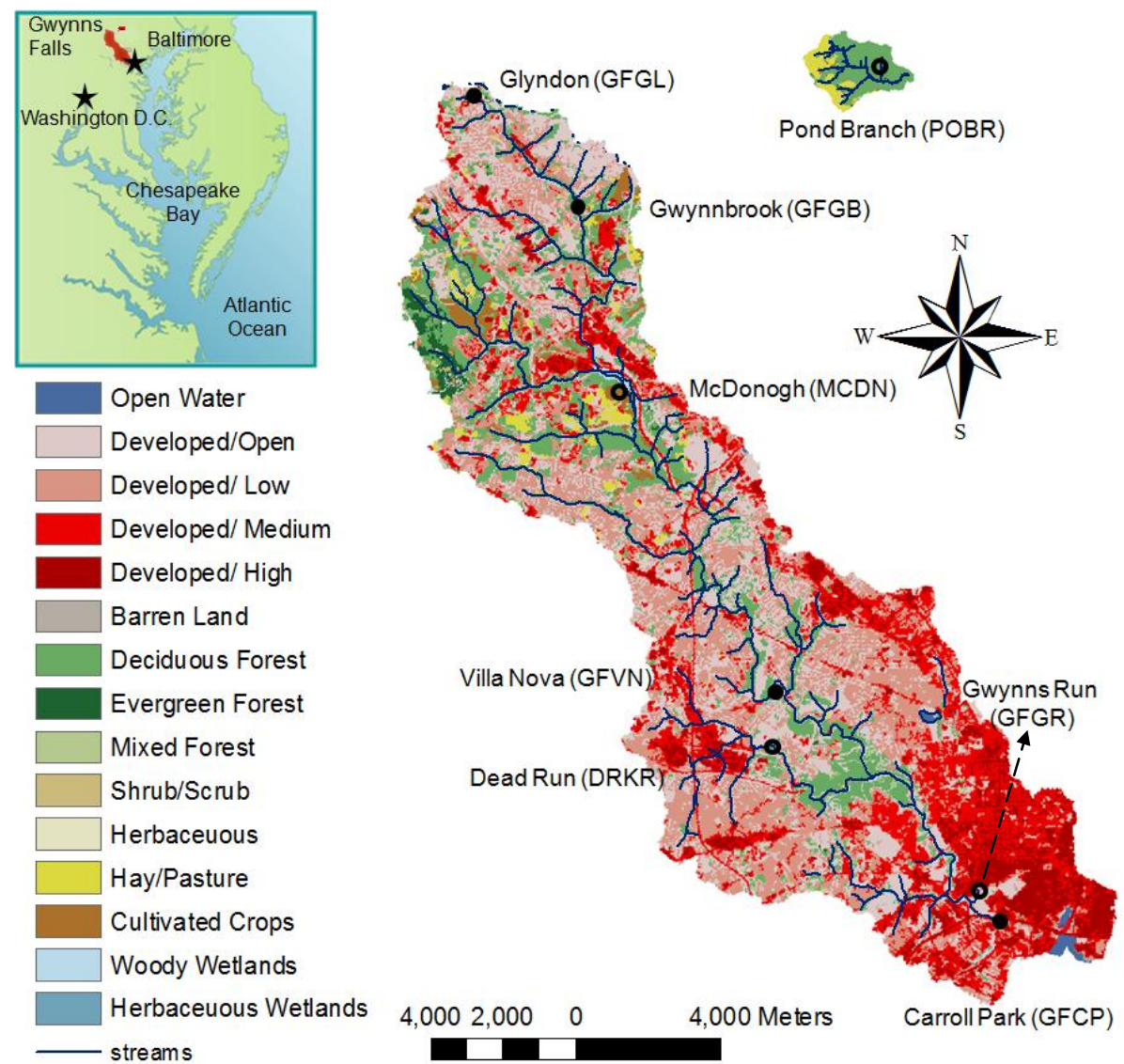

Fig. 1. Land use of the Gwynns Falls and Pond Branch watersheds, showing sites from which sediment and water were collected for incubations. Pond Branch is a watershed with forest as the dominant land use, and it is located in the nearby Gunpowder River. Solid and open circles represent sites of the main stem and tributaries, respectively. Resolution of the land use data is $30 \mathrm{~m}$, and land use and stream channel location data are from US Department of Agriculture (dtagateway.nrcs.usda.gove) and US Geological Survey (http://datagateway. nrcs.usda.gov/). 


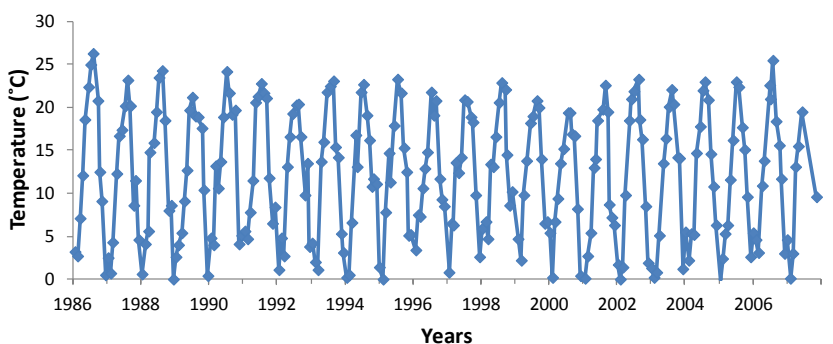

Fig. 2. Time series of water temperature at the Gwynns Falls at Villa Nova (GFVN), the urban site with longest historical data. Water temperature were recorded monthly. No trend of decrease or increase was observed for annual mean, maximal and minimal water temperature ( $p>0.05$, linear regression).

\subsection{Sample collection and processing}

Sediment and water samples were collected from all 8 sites on 2 April 2010, when the streams were at baseflow conditions. Sediment samples at each site comprised material taken from 4 cross-section lines perpendicular to stream flow within $50 \mathrm{~m}$ of the primary sampling site. Along each crosssection line, surface sediments at three sites (left, middle and right) were collected. All sediments collected at these sites were well-mixed to make a composite sample. Three liters of stream water were collected during the sediment sampling for later incubation experiments and water quality analyses. Water and sediment samples were kept cold on ice during transfer to the lab, where they were temporarily kept refrigerated. In the lab, sediments were sieved through a $2-\mathrm{mm}$ sieve, and the fractions $<2 \mathrm{~mm}$ were homogenized and kept cold for incubations.

\subsection{Sediment incubations}

The sediments were incubated in 4 environmental control chambers with temperatures set at $4,15,25$, and $35^{\circ} \mathrm{C}$, respectively. Long-term water temperatures in the Gwynns Falls were generally within 0 to $30^{\circ} \mathrm{C}$. A higher incubating temperature was also used here, considering a possible 4$5^{\circ} \mathrm{C}$ warming in the future. At each temperature, $200 \mathrm{~g}$ of wet sediment and $450 \mathrm{~mL}$ of unfiltered stream water were added to a $500 \mathrm{~mL}$ glass flask. Sediment and water in the flasks were incubated in the dark and gently stirred with a shaker table to simulate water movement in streams. Dark incubations were used because heterotrophic bacteria are important in sediment transformations of bioreactive elements, although algae can also play a role in assimilating inorganic $\mathrm{N}$ and $\mathrm{P}$. Water samples without sediment additions were also prepared in $500 \mathrm{~mL}$ flasks at the same time as controls. Four sets of flasks ( 8 samples with 8 controls for each set) were placed in 4 environmental control chambers. During the 2day incubations, $30 \mathrm{~mL}$ of water were collected at $0,6,12$, 24 , and $48 \mathrm{~h}$ increments and filtered immediately through $25 \mathrm{~mm}$ Whatman GF/F filters in a syringe filter. The filtrates were stored in combusted amber glass vials and stored in a refrigerator. Sediments were collected before incubations for size fractionation and chemical analyses to examine their effect on bioreactive element fluxes and transformation. Sediment samples were dried at $40{ }^{\circ} \mathrm{C}$ for three days, and the dried sediments were fractionated into 5 size fractions with a set of sieves $(0.5 \mathrm{~mm}, 0.25 \mathrm{~mm}, 0.125 \mathrm{~mm}$ and $0.0625 \mathrm{~mm})$ and weighed for particle size analysis. The bulk sediments from each size fractionation were ground with a mortar and pestle, and the powder was saved for chemical analyses.

\subsection{Chemical analysis}

DOC concentrations were measured on a Shimadzu Total Organic Carbon Analyzer (TOC-V CPH/CPN), by using hightemperature catalytic oxidation. $\mathrm{HCl}$ was added to remove dissolved inorganic carbon with a 1-min sparge time. Three injections (with a maximum of 5 times) were run for each sample to obtain a standard derivation less than 0.2. Fluorescence spectroscopy was used in characterization of DOC composition and source. Fluorescence measurements were made on a FluoroMax-4 Spectrofluorometer (Horiba Jobin Yvon, Edison NJ, USA) using a $1 \mathrm{~cm}$ quartz cuvette with slit widths set to $5 \mathrm{~nm}$. Excitation emission matrix scans (EEMs) were obtained by collecting a series of emission wavelengths ranging from 300 to $600 \mathrm{~nm}$ ( $2 \mathrm{~nm}$ increments) at excitation wavelengths ranging from 240 to $450 \mathrm{~nm}$ ( $5 \mathrm{~nm}$ increments). Instrument biases such as excitation and emission monochromators (as well as bulb life and efficiency) were automatically corrected. After data acquisition on the spectrofluorometer, the raw data was exported into MATLAB for remaining corrections (e.g., inner filtering and scatter removal; Walker et al., 2009). The calibrated values of fluorescence intensities at excitation/emission $=275 \mathrm{~nm} / 240 \mathrm{~nm}$ and $350 \mathrm{~nm} / 480 \mathrm{~nm}$ were recorded as protein-like and humic-like fluorospores (Coble, 1996; Stolpe et al., 2010). Relative to the humic-like fluorospore, the intensity of the protein-like fluorospore is generally higher in labile DOC sources (e.g., wastewater; Hudson et al., 2007) and positively correlated with DOC bioavailability (Balcarczyk et al., 2009; Lønborg et al., 2010). So, the ratio of protein-like to the humic-like fluorospore $(\mathrm{P} / \mathrm{H})$ was calculated here as an index for organic carbon lability.

Nitrate, sulfate and chloride ion $\left(\mathrm{Cl}^{-}\right)$concentrations were measured with a Dionex ICS-1500 ion chromatograph (ICS1500, Dionex INC., USA). The instrument was equipped with an AS14 2-mm analytical column and an AG14 2-mm guard column. An eluent of $3.5 \mathrm{mM}$ of $\mathrm{Na}_{2} \mathrm{CO}_{3}$ with $1.0 \mathrm{mM}$ $\mathrm{NaHCO}_{3}$ was used and a flow rate was set at $0.3 \mathrm{~mL} \mathrm{~min}^{-1}$. An internal standard was run every 12 samples, and one check standard that was provided by Dionex was run for each set of samples. Chloride ion $\left(\mathrm{Cl}^{-}\right)$was used as a conservative tracer to normalize the effect of evaporation during incubations, which may change the water volume and concentrations. We assumed that there was no $\mathrm{Cl}^{-}$exchange between 
water and sediment. SRP was measured colorimetrically on a Thermo Fisher Scientific spectrophotometer, using the ascorbic acid-molybdate blue method (Murphy and Riley, 1962).

The ground sediment samples were weighed in tin boats, and vapor-phase acidified overnight in a desiccator with $\mathrm{HCl}$ (fuming) to remove carbonates. The acidified samples were transferred back to the drying oven $\left(60^{\circ} \mathrm{C}\right)$ again to remove $\mathrm{HCl}$ vapor residual, before being shipped to the Stable Isotope Facility at UC Davis for carbon and nitrogen isotope analyses. Carbon and nitrogen isotopic compositions $\left(\delta^{15} \mathrm{~N}\right.$ and $\delta^{13} \mathrm{C}$ ) were determined by CF-IRMS and an elemental analyzer that converted organic $\mathrm{N}$ into $\mathrm{N}_{2}$ gas and organic $\mathrm{C}$ into $\mathrm{CO}_{2}$ gas. Precision was $0.3 \%$ for $\delta^{15} \mathrm{~N}$ and $0.2 \%$ for $\delta^{13} \mathrm{C}$ for replicate analyses of reference standards. Sediment ash weight was calculated as the difference in weight before and after being combusted at $650^{\circ} \mathrm{C}$ for $4 \mathrm{~h}$. Before combustion, sediments were dried at $90^{\circ} \mathrm{C}$ for $4 \mathrm{~h}$ to remove water. Ash weights were determined in triplicates.

\subsection{Data analysis and statistics}

Sediment fluxes per unit area were calculated by dividing the net changes in the masses of DOC, nitrate, SRP or sulfate with the area of water-sediment interface and the time of incubation period $(48 \mathrm{~h})$. The values for nitrate and sulfate are presented as nitrate- $\mathrm{N}$ and Sulfate-S. The changes in the control flask (with water only), occurring in water without sediments, were subtracted to obtain the fluxes that were released from sediments. Positive and negative values represent net release from sediments or retention by sediments, respectively. We performed regressions of sediment biogeochemical fluxes with temperature site by site. If the p-value was $<0.05$ for the regression, we assumed there was a significant temperature effect. Three types of regressions were used: exponential, logarithmic and linear. The first two were based on different phases of bacterial growth curves, because many transformations of $\mathrm{C}, \mathrm{N}, \mathrm{P}$ and $\mathrm{S}$ are biologically mediated. Temperature can stimulate bacterial growth rate and corresponding microbial biogeochemical functions as a mechanism relevant to changes during incubations. Exponential regressions were consistent with the exponential phase of bacterial growth during short incubation time, while logarithmic regressions represented another phase of the bacterial growth curve that potentially involves microbial effects of denitrification and sulfate reduction when oxygen was depleted. Linear regression was only used to describe the change in ratios for DOM composition as well as changes in response to watershed characteristics such as percentage impervious surface cover (\% ISC), considering that these controls do not directly involve bacterial growth rates. Relationships between sediment fluxes and water quality or sediment characteristics were also examined to test possible mechanisms for land use effects. For linear relationships, Spearman's correlation was used in cases where assumptions of normality were not met. For non-linear relationships, curve estimations were performed and the best type of estimate (with lowest p-value) was selected.

The relationship between temperature and sediment biogeochemical fluxes at individual sites was used to estimate the contributions of SRP, DOC, nitrate, and sulfate loads from sediment to stream loads, as well as to predict an increase in sediment fluxes with warming by $5^{\circ} \mathrm{C}$. Water temperature was taken from the BES LTER website, where mean daily water temperature data are available from the period from 1 October 2006 to 30 September 2007 for all the study sites (courtesy K. Belt and E. Noonan, US Forest Service). Monthly averaged temperatures were used for sediment biogeochemical flux estimations. The width of the stream channel, measured monthly from July 2009 to June 2010 over an annual period, was to estimate water-sediment interaction area, while stream length of tributaries (upstream of a sample site to the headwaters) and main stem section (one sample site and the nearest downstream site) was estimated from a Geographical Information System map (nhd.USGS. gov/data.html). Mean width of sections of the Gwynns Falls main stem and tributaries were calculated differently. The values for measured sections of the main stem (between two sites) were the averages of the beginning and the ending stations for each reach. The cross section of the tributaries was measured at the downstream location, but not measured at the upstream location. The upstream location of the tributary reach was assumed to be $\sim 2 / 3$ of the downstream location based on previous measurements of stream cross sections in these BES LTER streams (Sivirichi et al., 2011).

\section{Results}

\subsection{Water and sediment chemistry}

As expected, chemistry of streamwater that was used for incubations varied across land use (Table 2). DOC concentrations and protein-like to humic-like fluorescence $(\mathrm{P} / \mathrm{H}) \mathrm{ra}-$ tios increased with impervious surface cover, but the relationship was not significant $\left(R^{2}=0.29\right.$ and $0.26, p=0.17$ and 0.20 ). Concentrations of SRP and sulfate significantly increased with impervious surface cover $\left(R^{2}=0.72\right.$ and 0.92 , $p=0.007$ and 0.000$)$. Nitrate concentrations were variable but higher at sites of the upper Gwynns Falls (GFGB, GFGL and MCDN) and an urban site with a sewage leak (GFGR) (Kaushal et al., 2011).

Sediment size fractionation varied with stream size and land use (Table 2), but showed an increase in particle size along the main stem of the Gwynns Falls and with increasing watershed urbanization. The $\%$ ash weight increased from $1.3 \%$ at the forest site (POBR) to 3.8-6.7\% at the degraded urban sites DRKR and GFGR, and it was positively correlated with impervious surface cover $\left(R^{2}=0.85, p=0.001\right)$. Similarly, $\delta^{15} \mathrm{~N}$ increased from $0.63 \%$ at the forest site to $1.95-1.89 \%$ at the degraded urban sites. 
Table 2. Water chemistry, sediment size fractions, ash free weight (ash wt \%) and sediment isotopic composition prior to incubation experiments.

\begin{tabular}{|c|c|c|c|c|c|c|c|c|c|}
\hline Site & Variables & $\begin{array}{r}\text { POBR } \\
\text { forest }\end{array}$ & $\begin{array}{r}\text { MCDN } \\
\text { agriculture }\end{array}$ & $\begin{array}{r}\text { GFGB } \\
\text { suburban }\end{array}$ & $\begin{array}{r}\text { GFGL } \\
\text { suburban }\end{array}$ & $\begin{array}{r}\text { GFVN } \\
\text { suburban }\end{array}$ & $\begin{array}{l}\text { GFCP } \\
\text { urban }\end{array}$ & $\begin{array}{r}\text { DRKR } \\
\text { urban }\end{array}$ & $\begin{array}{r}\text { GFGR } \\
\text { urban }\end{array}$ \\
\hline \multirow{5}{*}{ 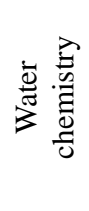 } & $\operatorname{DOC}\left(\mathrm{mg} \mathrm{L}^{-1}\right)$ & 1.89 & 1.82 & 1.95 & 4.37 & 2.12 & 2.78 & 3.59 & 3.00 \\
\hline & $\mathrm{P} / \mathrm{H}$ ratio & 0.40 & 0.41 & 0.39 & 0.28 & 0.42 & 0.49 & 0.48 & 0.48 \\
\hline & $\mathrm{NO}_{3}-\mathrm{N}\left(\mathrm{mg} \mathrm{L}^{-1}\right)$ & 0.01 & 1.37 & 1.92 & 1.18 & 1.16 & 0.89 & 0.56 & 2.23 \\
\hline & $\operatorname{SRP}\left(\mu \mathrm{gL}^{-1}\right)$ & 1.15 & 1.67 & 2.97 & 4.48 & 3.28 & 4.85 & 7.93 & 33.5 \\
\hline & $\mathrm{SO}_{4}-\mathrm{S}\left(\mathrm{mg} \mathrm{L}^{-1}\right)$ & 2.0 & 8.3 & 6.6 & 23.5 & 10.9 & 18.6 & 34.0 & 53.7 \\
\hline \multirow{6}{*}{ 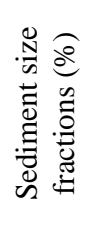 } & $<0.0625 \mathrm{~mm}$ & 0.5 & 1.6 & 0.8 & 2.6 & 0.6 & 0.2 & 1.4 & 0.03 \\
\hline & $0.0625-0.125 \mathrm{~mm}$ & 0.6 & 1.8 & 1.0 & 2.5 & 0.9 & 0.2 & 1.7 & 0.03 \\
\hline & $0.125-0.25 \mathrm{~mm}$ & 3.3 & 11.4 & 7.6 & 11.8 & 4.7 & 1.1 & 8.5 & 0.6 \\
\hline & $0.25-0.5 \mathrm{~mm}$ & 9.5 & 46.4 & 19.7 & 37.5 & 13.8 & 4.8 & 15.6 & 2.8 \\
\hline & $2-0.5 \mathrm{~mm}$ & 37.1 & 34.9 & 36.9 & 37.0 & 25.5 & 41.2 & 21.8 & 21.2 \\
\hline & $>2 \mathrm{~mm}$ & 49.0 & 3.9 & 33.9 & 8.6 & 54.5 & 52.4 & 51.0 & 75.4 \\
\hline \multirow{3}{*}{ 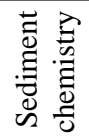 } & Ash wt (\%) & 1.3 & 2.0 & 1.4 & 2.7 & 1.8 & 2.7 & 3.8 & 6.7 \\
\hline & $\delta^{13} \mathrm{C}(\% \circ)$ & -27.3 & -25.5 & -25.5 & -25.6 & -25.5 & -21.4 & -19.6 & -27.3 \\
\hline & $\delta^{15} \mathrm{~N}(\% \circ)$ & 0.63 & 1.50 & 1.30 & 1.20 & 2.24 & 1.70 & 1.95 & 1.89 \\
\hline
\end{tabular}

\subsection{Temperature controls on sediment DOC fluxes and composition}

Warming clearly altered the amount and quality of DOC from sediments. Increases in DOC concentration and humic-like fluorescence and decreases in protein to humic $(\mathrm{P} / \mathrm{H})$ ratio occurred for all sites during the time course of the 48-h incubations at temperatures $\geq 15^{\circ} \mathrm{C}$, with larger changes observed at higher incubation temperatures (Fig. 3).

Sediment fluxes of DOC and changes in DOC composition (humic-like and protein-like fluorescence and their ratio) at the end of the incubations displayed consistent positive temperature effects (Fig. 4). The fluxes of DOC and changes in humic-like and protein-like fluorescence all exponentially increased with temperature except for DOC at POBR. However, the temperature effects on $\mathrm{P} / \mathrm{H}$ ratio were consistently negative and linear (Fig. 4).

\subsection{Temperature controls on concentrations and fluxes of SRP, sulfate and nitrate}

During the time course of the incubations, the effects of temperature differed for SRP, sulfate and nitrate concentrations. In general, SRP concentrations gradually increased during the incubations at temperatures $\geq 15^{\circ} \mathrm{C}$, with larger increases observed at higher incubation temperatures (Fig. 5 left panels). Sulfate concentrations also displayed a similar trend of change to that of SRP at rural (POBR and MCDN) and suburban (GFGL and GFGB) sites (Fig. 5 middle panels), although the increases $\left(<2 \mathrm{mg} \mathrm{L}^{-1}\right)$ were generally minor relative to stream sulfate levels $\left(2-54 \mathrm{mg} \mathrm{L}^{-1}\right)$. Interestingly, sulfate concentrations at 3 urban sites (GFVN, GFGR and DRKR) showed substantial decreases during the later stage of the incubation at 25 and $35^{\circ} \mathrm{C}$ (e.g., up to 0.81 to $19.3 \mathrm{mg} \mathrm{L}^{-1}$ or $7 \%$ to $40 \%$ at $35^{\circ} \mathrm{C}$ ). The forest site (POBR) exhibited a linear increase in nitrate concentrations, while the agricultural site (MCDN) exhibited a linear decrease in nitrate concentrations (Fig. 5 right panels). At suburban/urban sites, nitrate showed a gradual decrease in the beginning of the incubations followed by an increase during the later stage.

There were also clear changes in fluxes of major bioreactive elements from sediments in response to warming (Fig. 6). SRP fluxes exponentially increased with temperature at all sites, with values varying from retention or minor release at $4{ }^{\circ} \mathrm{C}$ to the greatest release at $35^{\circ} \mathrm{C}$. Sulfate fluxes were generally positive at GFCP and the less-developed sites (POBR, MCDN, GFGL and GFGB), and there was an exponential trend of increase in sulfate fluxes with temperature at 3 sites. Sulfate fluxes at 3 urban sites (GFVN, DRKR and GFGR) increased from 4 to $15^{\circ} \mathrm{C}$, but then decreased to negative values at a higher temperature range (from 15 to $35^{\circ} \mathrm{C}$ ). Temperature effects on nitrate fluxes were complicated and showed no clear pattern. There was a significant trend of exponential increase in nitrate fluxes with temperature at 2 urban sites (DRKR and GFGR).

\subsection{Effects of land use on sediment fluxes}

Sediment fluxes also showed the influence of urban land use, indicated by the fraction of watershed impervious surface cover. For SRP and nitrate, sediment fluxes were positively correlated with watershed impervious surface cover at $35^{\circ} \mathrm{C}$ and $25^{\circ} \mathrm{C}$ (for SRP only) (Fig. 7), and the correlation became less significant and negative at lower temperatures. In contrast, sulfate fluxes were positively correlated to watershed 

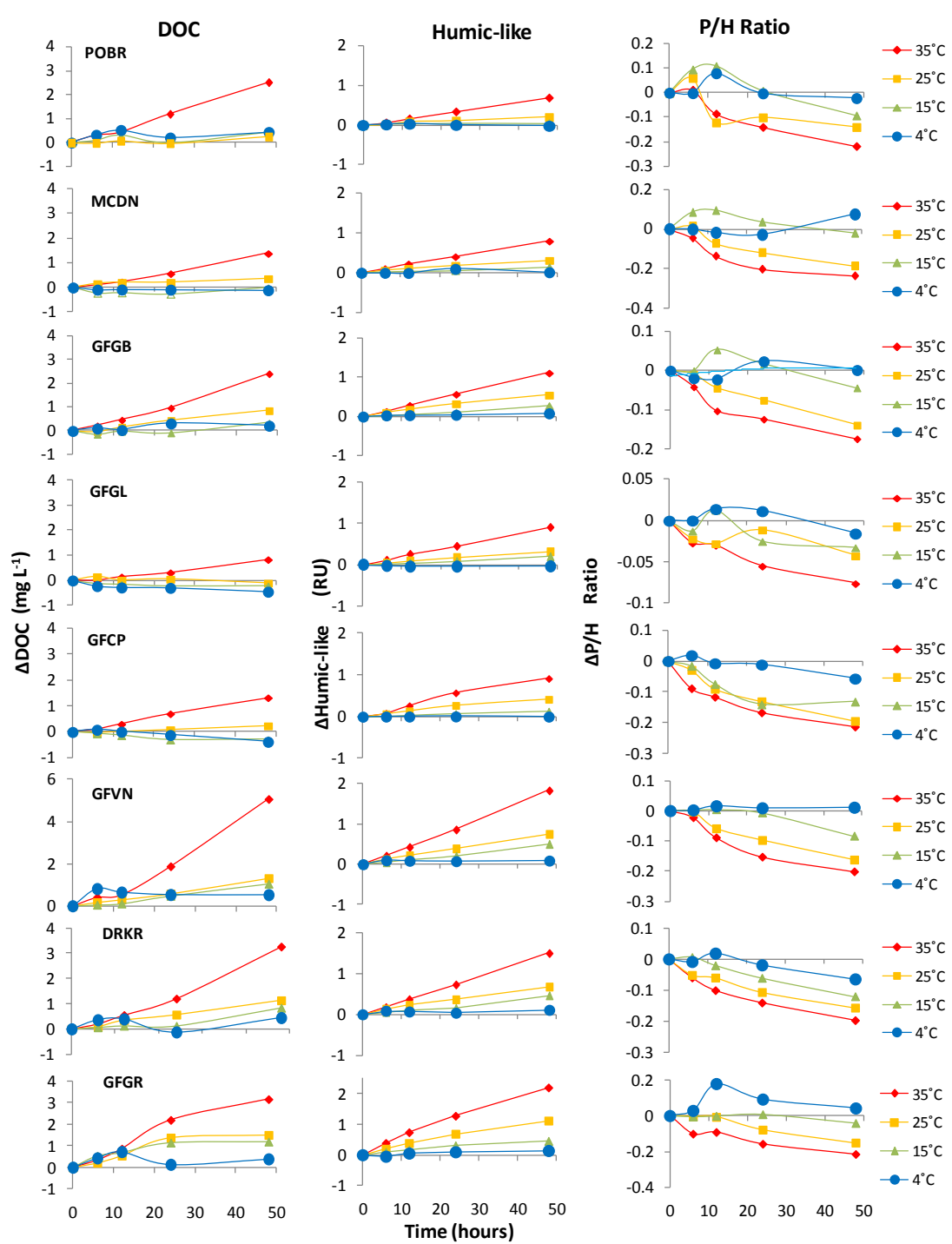

Fig. 3. Changes in DOC concentration, humic-like fluorescence (in Raman Unit, or RU) and protein to humic ratio (P/H ratio) during the 48-h sediment incubations, relative to initial values before incubation. Humic-like fluorescence is in Raman Unit (RU).

impervious surface cover at $4{ }^{\circ} \mathrm{C}$ and $15^{\circ} \mathrm{C}$ and negatively correlated with watershed impervious surface cover at $25^{\circ} \mathrm{C}$ and $35^{\circ} \mathrm{C}$. There were no strong correlations between DOC fluxes and watershed impervious surface cover $\left(r^{2}<0.1\right.$, $p>0.05)$.

Sediment composition and water chemistry were potential explanatory variables for the above urbanization effect. The correlations of percent ash free weight with sediment fluxes of sulfate, SRP or nitrate across temperature were similar to those with watershed impervious surface cover (Fig. 7). In addition, sediment $\delta^{15} \mathrm{~N}$ at $35^{\circ} \mathrm{C}$ was also positively correlated with SRP flux $\left(r^{2}=0.58, p<0.05\right)$. Correlations with stream water SRP concentration at $35^{\circ} \mathrm{C}$ were positive for SRP and nitrate fluxes $\left(r^{2}=0.53\right.$ and $\left.0.64, p<0.05\right)$ but negative for sulfate $\left(r^{2}=0.92, p<0.05\right)$.

\subsection{Predicting sediment flux estimates with warming}

Using the regression curves describing the changes in sediment fluxes with temperature (Fig. 4), we crudely estimate current sediment fluxes and their changes with a $5{ }^{\circ} \mathrm{C}$ warming in stream temperature (Table 3 ). We predict that a $5^{\circ} \mathrm{C}$ warming would increase the SRP flux from sediment by 0.27 to $1.37 \mathrm{~g} \mathrm{~m}^{-2} \mathrm{yr}^{-1}$, with the highest at GFGR and the lowest value at POBR. The estimated sediment release of each stream section accounted for 2.6-21.4\% of stream SRP loads. Similarly, we estimate sediment nitrate flux accounts for $1-26 \%$ of total stream nitrate load (except $696 \%$ for POBR), and a $5{ }^{\circ} \mathrm{C}$ warming would increases sediment DOC flux by $0.030-0.14 \mathrm{~kg} \mathrm{~m}^{-2} \mathrm{yr}^{-1}$. A $5^{\circ} \mathrm{C}$ warming would increase sediment nitrate flux by $0.001-0.06 \mathrm{~kg} \mathrm{~m}^{-2} \mathrm{yr}^{-1}$. The $20 \%$ increase in nitrate flux at POBR is consistent with 


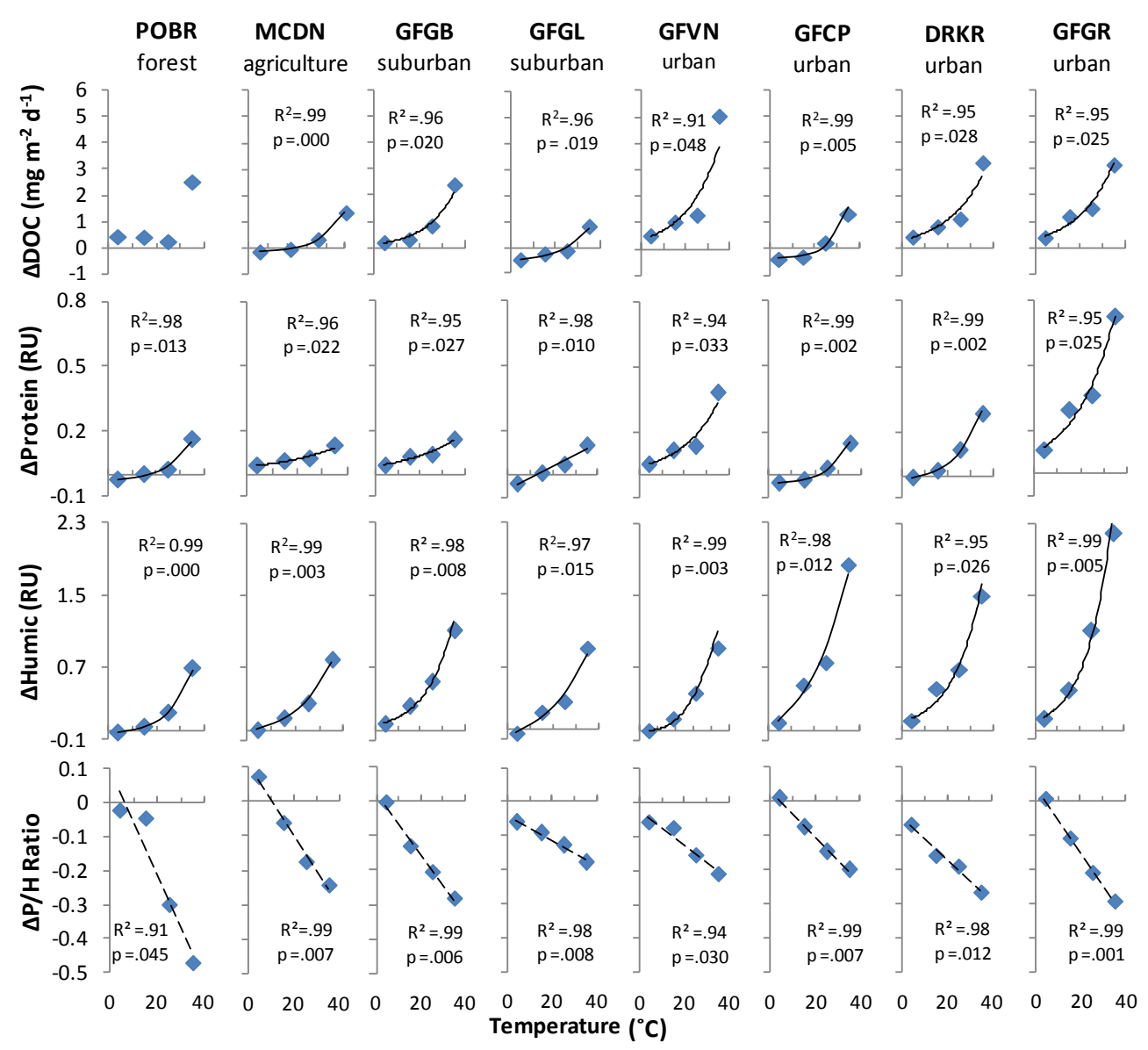

Fig. 4. Plots of DOC flux, or changes in protein-like fluorescence, humic-like fluorescence and their $(\mathrm{P} / \mathrm{H})$ ratio versus incubation temperature. Best fit regressions were exponential for DOC flux, or changes in protein-like fluorescence, humic-like fluorescence (in solid) and linear for $\mathrm{P} / \mathrm{H}$ ratio (in dash). Regression without significant $<0.05$ (DOC at POBR) was not added. Protein-like and humic-like fluorescence are in Raman Unit (RU).

Table 3. Estimated sediment biogeochemical fluxes from stream sediments without (current ambient temperatures) and with increases in $5{ }^{\circ} \mathrm{C}$-warming.

\begin{tabular}{|c|c|c|c|c|c|c|c|c|}
\hline & \multicolumn{2}{|c|}{$\operatorname{SRP}\left(\mathrm{g} \mathrm{m}^{-2} \mathrm{yr}^{-1}\right)$} & \multicolumn{2}{|c|}{ DOC $\left(\mathrm{kg} \mathrm{m}^{-2} \mathrm{yr}^{-1}\right)$} & \multicolumn{2}{|c|}{$\mathrm{SO}_{4}^{2-}-\mathrm{S}\left(\mathrm{kg} \mathrm{m}^{-2} \mathrm{yr}^{-1}\right)$} & \multicolumn{2}{|c|}{$\mathrm{NO}_{3}^{-}-\mathrm{N}\left(\mathrm{kg} \mathrm{m}^{-2} \mathrm{yr}^{-1}\right)$} \\
\hline & current & $\Delta$ warming $*$ & current & $\Delta$ warming & current & $\Delta$ warming & current & $\Delta$ warming \\
\hline GFGR & 0.39 & 1.37 & 0.37 & 0.13 & 0.05 & -0.61 & -0.07 & 0.06 \\
\hline DRKR & 0.53 & 0.53 & 0.28 & 0.10 & -0.11 & -0.03 & -0.02 & 0.03 \\
\hline GFCP & 0.53 & 0.76 & -0.09 & 0.06 & 0.14 & 0.03 & 0.04 & 0.02 \\
\hline GFVN & 0.66 & 0.91 & 0.35 & 0.14 & 0.04 & 0.00 & -0.08 & 0.00 \\
\hline GFGL & 0.71 & 0.55 & -0.13 & 0.03 & 0.00 & 0.04 & -0.03 & 0.01 \\
\hline GFGB & -0.14 & 0.41 & 0.10 & 0.07 & 0.06 & 0.02 & -0.06 & 0.02 \\
\hline MCDN & 0.12 & 0.28 & -0.01 & 0.05 & 0.10 & 0.02 & -0.02 & 0.00 \\
\hline POBR & -0.07 & 0.27 & 0.19 & 0.11 & 0.01 & 0.00 & 0.03 & 0.01 \\
\hline
\end{tabular}

$* \Delta$ warming is the change in sediment fluxes with $5^{\circ} \mathrm{C}$-warming.

results of a recent field study (over $7 \mathrm{yr}$ ) studying effects of experimental soil warming $\left(5^{\circ} \mathrm{C}\right.$ above ambient) at a forest site (Butler et al., 2012) showing temperature effects on net nitrogen mineralization. Temperature effects on sulfate flux varied across rural and urban sites. We predicted $5^{\circ} \mathrm{C}$ warming would slightly increase sulfate fluxes ranging from $0.0004-0.04 \mathrm{~kg} \mathrm{~m}^{-2} \mathrm{yr}^{-1}$ at less-developed sites but decrease the flux by $0.0005-0.61 \mathrm{~kg} \mathrm{~m}^{-2} \mathrm{yr}^{-1}$ at the 3 urban sites. 

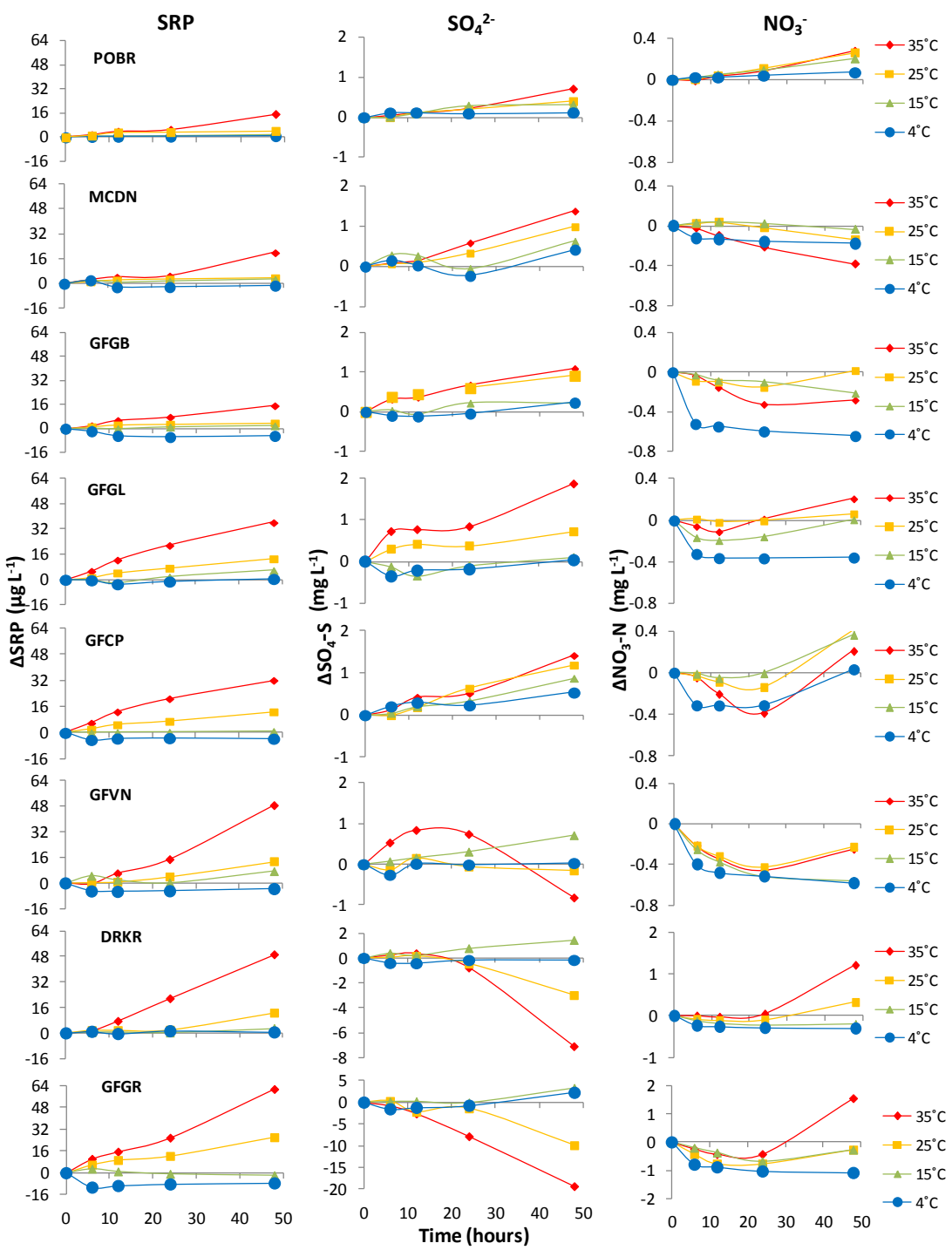

Fig. 5. Changes in nitrate, SRP and sulfate concentrations during the 48 -h sediment incubations, relative to initial values before incubations.

\section{Discussion}

\subsection{Effects of temperature on transformations and fluxes of DOC, nitrate, SRP and sulfate}

Temperature had substantial effects on biogeochemical fluxes in stream sediments across land use and indicated the importance of warming on influencing coupled biogeochemical cycles. The observed changes in DOC, nitrate, SRP and sulfate during the incubations were a result of temperature-dependent transformations of carbon, nitrate, phosphorus and sulfur. The impacts of warming on cycling of individual bioreactive elements is discussed more fully below.

Because decomposition of sedimentary organic matter is a process that can be stimulated by warming (White et al., 1991; Arnosti et al., 1998; Gudasz et al., 2010), DOC, the intermediate product of sedimentary organic carbon decomposition, can be released to the water column with increased temperature. Consistent temperature-enhanced DOC fluxes across sites in this study (Figs. 3 and 4) have been reported in lab experiments with sediments, soils and mor humus (Christ and David, 1996; Andersson et al., 2000; Marschner and Bredow, 2002) and field temperature manipulations of shallow aquifers (Wilson and Williams, 2006). The pattern of increasing DOC flux across time in response to warming may be linked to the exponential growth phase of bacteria, which can occur during the incubation period. Although DOC release from sediments or soils can be either abiotic (e.g., DOC dissolution and abiotic oxidation) and/or biotically mediated (via fungi and heterotrophic bacteria), the latter is generally considered to be far more important than the former (Aguilar and Thibodeaux, 2005). Our results indicate 


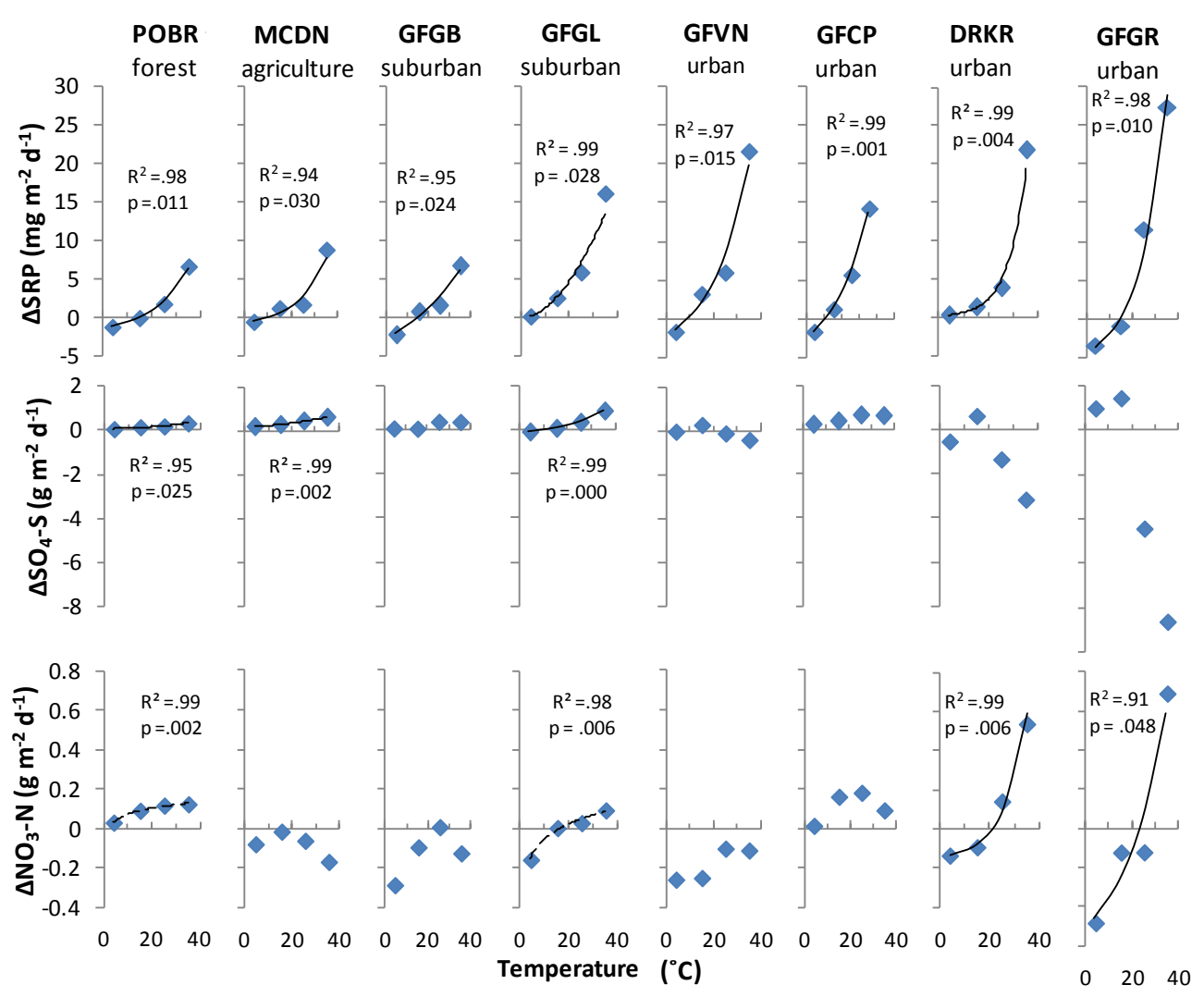

Fig. 6. Plots of SRP, sulfate and nitrate fluxes versus incubation temperature. Best fit regressions were exponential for SRP at all sites, and nitrate and sulfate at selected sites. Best fit regressions at POBR and GFGL were logarithmic (in dash). Regression fits were not included for sites without significant trends $(p>0.05)$.

that increased temperatures also influence the composition and lability of sediment-released DOC, with more humic substances than protein-like components at higher temperatures (Figs. 3 and 4). This change may be attributed to two possibilities: (1) sediment is enriched in humic substances (HS), and more HS is decomposed and released to water at higher temperatures, and/or (2) the released labile (proteinlike) fraction is preferentially used by microbes over the refractory (humic-like) component. In either case, DOC released from sediments will likely become more refractory in response to stream warming. This conclusion is similar to what has been found in soil warming experiments (Melillo et al., 2002, 2011) and decomposition of black carbon (Nguyen et al., 2010). Melillo et al. $(2002,2011)$ found that the labile soil carbon pool diminished and microbes adjusted to a more refractory carbon source over several years in response to soil warming $5{ }^{\circ} \mathrm{C}$ above ambient conditions. Similarly, Nguyen et al. (2010) reported that decomposition of more refractory carbon was more sensitive to increased temperature than less stable materials.

Temperature-enhanced $\mathrm{P}$ transformations and SRP fluxes from sediments have been widely observed in lab incubations (House and Denison, 2002; Suplee and Cotner, 2002; James and Barko, 2004; Schulz and Herzog, 2004) and field temperature manipulations (e.g., Zhang et al., 2012). The consistent temperature dependence of SRP fluxes across sites is related to the fact that organic $\mathrm{P}$ mineralization and $\mathrm{MnO}_{2} / \mathrm{Fe}_{2} \mathrm{O}_{3}$ reduction (two processes contributing to SRP release from sediments) can be enhanced at higher temperatures with intensifying organic matter (OM) decomposition. Evidence of $\mathrm{MnO}_{2} / \mathrm{Fe}_{2} \mathrm{O}_{3}$ reduction includes the study of House and Denison (2002), showing that equilibrium SRP concentrations under these anoxic conditions (in response to organic matter decomposition) are an order of magnitude higher than in oxic environments. Because phosphate cannot be removed via reduction reactions, it can accumulate in anoxic porewaters. Therefore, warmer temperatures can increase the water-sediment porewater SRP gradient, thereby facilitating the release of SRP from sediments to the water column (House and Denison, 2002).

In contrast to SRP, the role of sediment as a source or sink of nitrate and sulfate is the net result of organic $\mathrm{N}$ or $\mathrm{S}$ mineralization and/or nitrate and sulfate reduction. Denitrification (nitrate reduction) and nitrification (organic $\mathrm{N}$ oxidization) can both be increased as a function of temperature (Pfenning and McMahon, 1996; Saunders and Kalff, 2001; Carrera et al., 2003; Fdz-Polanco et al., 1994; Saidu, 2009). Thus, the effect of temperature on net nitrate release as a 
result of organic $\mathrm{N}$ mineralization may be partially counteracted by enhanced nitrate loss via denitrification and/or $\mathrm{N}$ immobilization. A few stream studies have shown that $\mathrm{N}$ immobilization into microbial cells occurs when labile carbon is present (Bernhardt and Likens, 2002; Kaushal and Lewis, 2005). Consequently, the patterns we observed for the changes in nitrate concentration were complicated (Fig. 5) and temperature effects on sediment nitrate fluxes were more variable than SRP and DOC (Fig. 6). More work is necessary investigating the changing influence of temperature and redox conditions on the relative importance of nitrification vs. denitrification vs. $\mathrm{N}$ immobilization in stream sediments.

Compared to nitrogen and phosphorus, little is known regarding temperature effects on sediment sulfate fluxes. Our results suggest that there can be significant temperature effects on sulfate fluxes at rural and suburban sites (Figs. 5 and 6). As discussed earlier, this positive effect can be attributed to temperature-enhanced release of sulfate with organic sulfur mineralization. The mechanism for sulfate retention at higher temperatures at urban sites (Figs. 5 and 6) is likely due to sulfate reduction. Evidence from incubations suggests that sulfate retention occurred during later stages following the occurrence of nitrate retention (Fig. 5); this is consistent with the early diagenesis model showing that sulfate is used later than nitrate as an electron receptor. Additionally, sulfate retention occurred at urban sites with higher temperatures, under which the intensive decomposition of labile organic matter may decrease redox potential to the threshold level for sulfate reduction. Therefore, temperature effects on sulfate fluxes can be either positive or negative, depending on whether sulfate acts as an electron receptor. More work is necessary characterizing the cycling of sulfur in urban streams and determining the relative importance of sulfate reduction as a competing process with denitrification.

\subsection{Response of sediment fluxes to warming across land use}

Our results indicate that the effects of temperature on sediment fluxes of DOC, nitrate, SRP and sulfate can increase across a rural-urban gradient (indicated by watershed impervious surface cover, Fig. 7), with a greater warming effect on sediments from urban rather than rural sites. The mechanism for greater response of sediment biogeochemical fluxes in urbanized watersheds can be explained by stream water chemistry and sediment composition. Table 2 and studies at the Baltimore LTER site have found that suburban and urban watersheds have higher concentrations of nitrogen, sulfur and phosphorus than forested watersheds (e.g., Groffman et al., 2004; Kaushal et al., 2008a; Duan et al., 2012; Kaushal and Belt, 2012), which provide nutrients for the growth of microbial communities. Prior studies have shown that the abundance and activity of bacteria and fungi, the organisms that transform organic $\mathrm{C}, \mathrm{N}, \mathrm{P}$ and $\mathrm{S}$, are generally

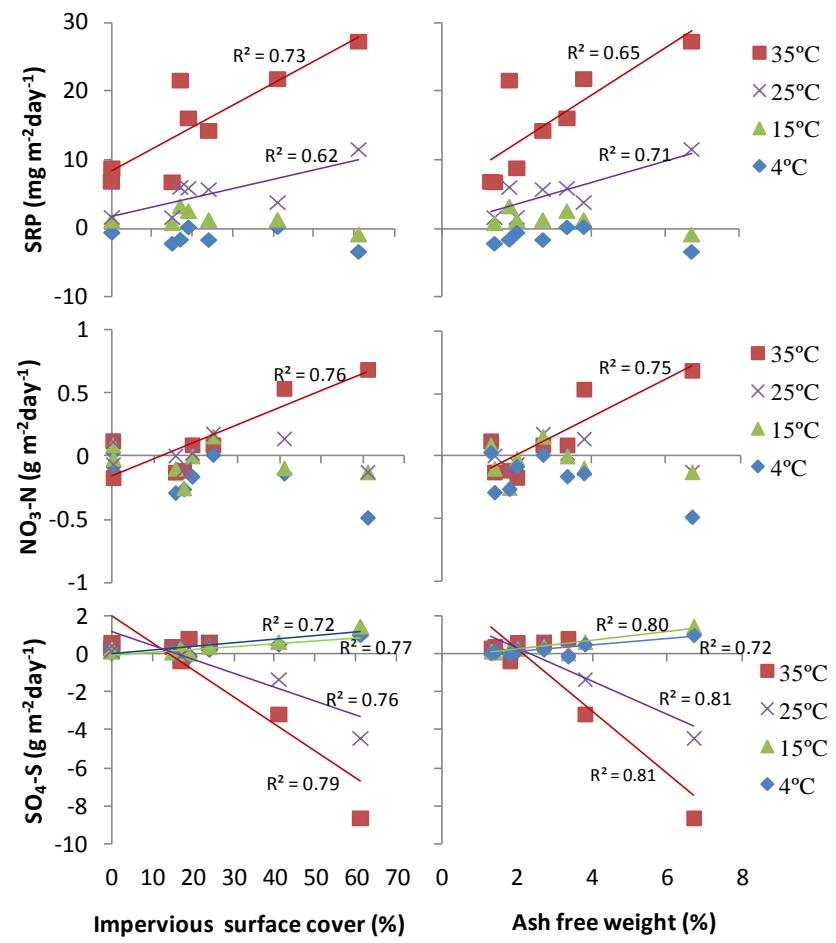

Fig. 7. Relationship of sediment fluxes of nitrate, SRP and sulfate with watershed impervious surface cover and percent of sediment ash weight. Best fit regressions were linear, and only regressions with significance $<0.05$ were applied. For the sulfate at $35^{\circ} \mathrm{C}$ incubations, the linear regression seems to be strongly influenced by the two heavily urbanized sites with highest $\%$ ash weight, while there is a large amount of cluster of data at lower impervious surface cover and lower \% ash weight.

higher in urban watersheds than rural watersheds (e.g., Imberger et al., 2008). The supporting evidence for nutrientstimulated microbial activities include that fluxes of SRP, nitrate and sulfate at $35^{\circ} \mathrm{C}$ were all correlated with stream water SRP $\left(r^{2}=0.53-0.90, p<0.05\right)-$ a potentially limiting nutrient in streams and master variable regulating biological processes in many freshwater ecosystems. Meanwhile, urbanization may also stimulate negating effects (e.g., pollutants) and bring higher stresses on bacteria and fungi in some urban streams. But it seems these potentially negating effects are relatively less important than the effects of temperature in our study watersheds.

Other work shows that biologically mediated transformation of $\mathrm{C}, \mathrm{N}, \mathrm{P}$ and $\mathrm{S}$ are highly dependent on organic matter quality because heterotrophic microbes require a carbon source (Arnosti et al., 1998; Schulz and Herzog, 2004; Kaushal and Lewis, 2005; Saidu, 2009; Zhang et al., 2012). Prior studies at the BES LTER site (e.g., Newcomer et al., 2012) show that organic matter composition or lability is an important variable influencing rate of denitrification. In this study, we found sediment organic matter (e.g., $\%$ ash weight) and isotopic composition (e.g., $\delta^{15} \mathrm{~N}$ ) were 
positively correlated with watershed land use (e.g., \% ISC). There were significant relationships between fluxes of nitrate, SRP and sulfate retention with sediment $\%$ ash weight $\left(r^{2}=0.65-0.80, p<0.05\right)$, which is a proxy for organic matter content in sediments; SRP flux was also positively correlated with $\delta^{15} \mathrm{~N}$ - a tracer for organic matter from sewage and manure sources, which are considered to be more labile than natural organic matter sources. Because of increased availability of limiting nutrients and labile organic carbon at urban sites, biotically mediated fluxes of nitrate, SRP and sulfate (retention or net release) can increase with urbanization (Fig. 7).

Sediment size, porosity, and composition may also play a role in the changes in sediment fluxes with land use. Larger porosity in coarse sediments may facilitate solute exchange between sediments and stream water and therefore may result in larger sediment fluxes. However, we did not find a coupling of sediment size with watershed impervious surface cover, although there was a trend of increase in sediment particle size with stream size (Table 2). We neither observed any significant correlation between sediment fluxes and sediment particle size. So, the effects of urbanization on fluxes of bioreactive elements seem less reflected in physical parameters of sediment than biogeochemical controls. Additionally, higher fluxes of DOC, SRP, nitrate and sulfate at urbanized sites can be directly attributed to higher contents of total organic carbon, nitrogen, phosphorus and sulfur in incubated sediments than those at the rural sites, but we did not account for all of these variables. Future studies should examine these factors in urban watersheds, and possible relationships to microbial community composition and organic matter bioavailability across sites.

\subsection{Predicting interactive effects of land use and warming in streams}

Several possible limitations may exist in our laboratory approaches to examine temperature effects on sediment transformations and fluxes of bioreactive element in streams. These limitations include no changes in sediment, stream flow and water chemistry, short incubation times, and lacks of light and diurnal changes and interaction between tributaries (Duan et al., 2011). All these complexities may limit the scaling of our results up to the real conditions in streams. Although further studies may need to consider complexities in streams, this study shows temperature effects do have important effects on sediment biogeochemical transformation and fluxes.

The potential interactive effects of land use and temperature on biogeochemical fluxes from stream sediments can be depicted in a hypothetical conceptual model predicting DOC, SRP, nitrate and sulfate fluxes (Fig. 8). As shown in the conceptual model, DOC fluxes from sediments may increase initially with stream temperature and watershed urbanization (indicated by impervious surface cover) due to more organic matter decomposition and transformation. But, the quality of DOC lability can be considerably reduced reflecting products of increased microbial metabolism. SRP fluxes may also increase with stream temperature and urbanization due to organic $\mathrm{P}$ mineralization and later on the desorption processes associated with reduction of magnesium/iron oxides and sulfate. Sulfate fluxes at rural sites may also increase due to organic sulfur mineralization, but there may be sulfate reduction at urban sites with high organic matter content and low redox potential (Fig. 8). Although less clear, we hypothesize that nitrate fluxes can increase at higher temperature and larger watershed impervious surface cover due to mineralization of nitrogen-enriched organic matter but are counteracted by a greater relative importance of denitrification and/or $\mathrm{N}$ immobilization at reduced redox conditions (Fig. 8). Given that temperature effects on $\mathrm{N}$ cycling varied across sites, our hypothesis regarding the effects of warming on shifts in the $\mathrm{N}$ cycle requires further testing.

Another implication from the conceptual model is that the relative importance of nitrate may be replaced by sulfate as an electron receptor for organic matter mineralization in some urban streams with low redox conditions and high levels of organic matter. Prior studies have shown that ammonia oxidation is coupled to the reductions of Mn oxides, Fe oxides and sulfate under anaerobic conditions (e.g., Giray and King, 1997; Clément et al., 2005; Javanaud et al., 2011). Our hypothesized replacement via sulfate reduction may occur due to increased labile DOC, low redox, and different microbial communities in urban environments. In particular, studies on sulfate reduction in hyporheic zones of urban streams are in need, because sulfate reduction can be linked to the geochemical cycles of mercury and metals (e.g., mercury methylation; Gilmour et al., 1992).

\section{Conclusions}

We found that warming water temperatures can significantly increase stream SRP concentrations, increase the quantity and decrease the quality of DOC, and potentially impact sulfur and nitrogen cycles. A $5{ }^{\circ} \mathrm{C}$ warming would substantially increase the SRP flux from sediment by $0.27-1.37 \mathrm{~g} \mathrm{~m}^{-2} \mathrm{yr}^{-1}$. An increase in SRP concentrations can influence downstream eutrophication potential and changes in carbon quality may impact food webs and microbial metabolism (e.g., Schindler et al., 1971; Godfrey and Mitchell, 1972). Warming may have the potential to influence net nitrogen mineralization in rural watersheds (Brookshire et al., 2011; Butler et al., 2012), but our results regarding warming effects on $\mathrm{N}$ fluxes show a larger variability. Sediment fluxes of SRP, nitrate and sulfate are all correlated with watershed impervious surface cover, and incubations suggest larger responses of sediment fluxes from streams draining urban land use than rural streams with the same range of temperature increase. Thus, larger changes in sediment fluxes of 


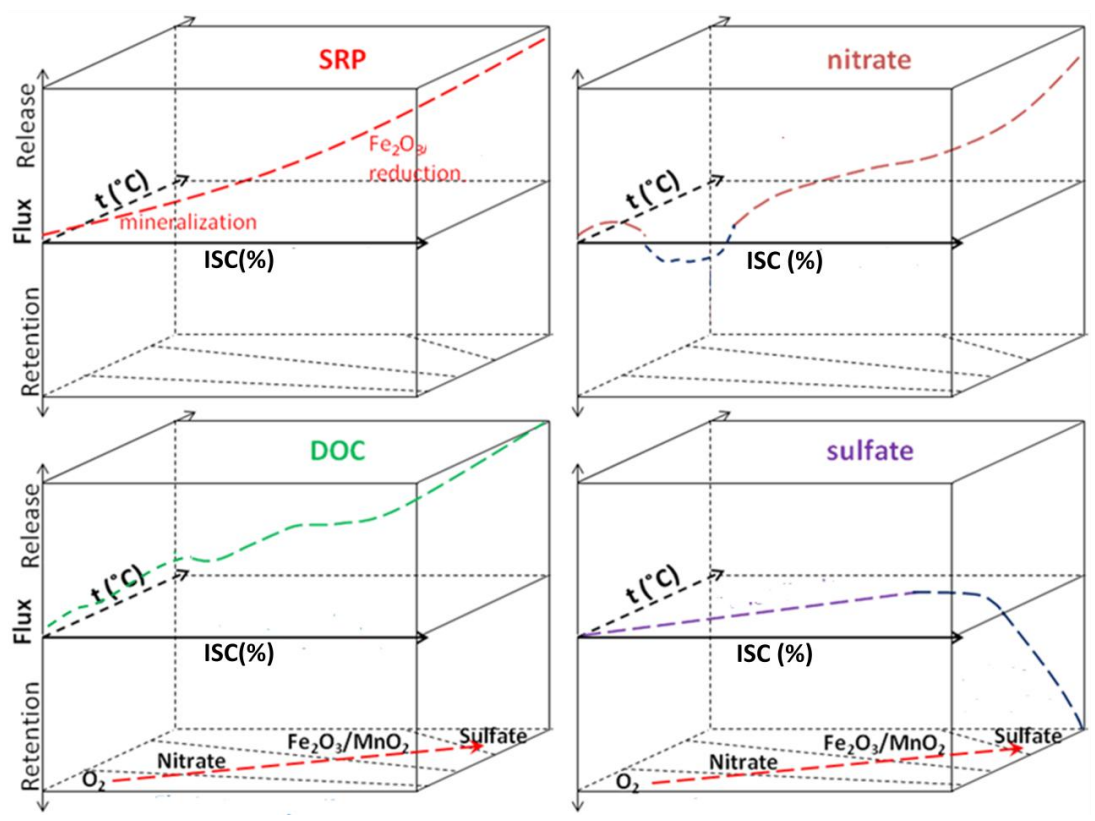

Fig. 8. Conceptual model of how temperature $(t)$ and land use interactively impact C, N, S, P fluxes in stream sediments. Land use effect is indicated by percent impervious surface cover (ISC \%). The area at the bottom of each box shows that oxygen $\left(\mathrm{O}_{2}\right), \mathrm{nitrate}_{\mathrm{Fe}} \mathrm{O}_{3} / \mathrm{MnO}_{2}$ and sulfate sequentially act as the primary electron acceptors as sedimentary organic matter decomposition intensifies with warming or ISC. Given that stream sediments are heterogeneous with respect to redox conditions, these reactions may occur simultaneously in streams in nature. Different colors are used to represent positive (release) and negative (retention) values for sediment fluxes.

bioreactive elements are expected in urban watersheds than rural watersheds with future global climate change. Further work is necessary regarding the impacts of stream warming on microbial processes, sulfur cycling, and coupled impacts on carbon, nitrogen, phosphorus, and metals in sediments of streams and rivers.

Acknowledgements. This research was supported by NSF Awards DBI 0640300 and CBET 1058502, NASA grant NASA NNX11AM28G, Maryland Sea Grant Awards SA7528085-U, R/WS-2 and NA05OAR4171042, and Baltimore Ecosystem Study LTER project (NSF DEB-0423476). K. Belt and E. Noonan of US Forest Service provided mean daily water temperature data of water year 2007 for flux predictions. We thank Tamara Newcomer, Michael Pennino and Rose Smith for valuable comments on a previous version of this manuscript.

Edited by: T. J. Battin

\section{References}

Aguilar, L. and Thibodeaux, L. J.: Kinetics of peat soil dissolved organic carbon release from bed sediment to water, Part 1, Laboratory simulation, Chemosphere, 58, 1309-1318, 2005.

Alexander, R. A., Smith, R. B., and Schwarz, G. E.: Effect of stream channel size on the delivery of nitrogen to the Gulf of Mexico, Nature, 403, 758-761, doi:10.1038/35001562, 2000.
Andersson, S., Nilsson, S. I., and Saetre, P.: Leaching of dissolved organic carbon (DOC) and dissolved organic nitrogen (DON) in mor humus as affected by temperature and $\mathrm{pH}$, Soil Biol. Biochem., 32, 1-10, doi:10.1016/S0038-0717(99)00103-0, 2000.

Arango, C. P., Tank, L. J. L., Johnson, T., and Hamilton, S. K.: Assimilatory uptake rather than nitrification and denitrification determines nitrogen removal patterns in streams of varying land use, Limnol. Oceanogr., 53, 2558-2572, 2008.

Arnosti, C., Jørgensen, B. B., Sagemann, J., and Thamdrup, B.: Temperature dependence of microbial degradation of organic matter in marine sediments: polysaccharide hydrolysis, oxygen consumption, and sulfate reduction, Mar. Ecol.-Prog. Ser., 165, 59-70, doi:10.3354/meps165059, 1998.

Balcarczyk, K. L., Jones, J. B., Jaffe, R., and Maie, N.: Stream dissolved organic matter bioavailability and composition in watersheds underlain with discontinuous permafrost, Biogeochemistry, 94, 255-270, doi:10.1007/s10533-009-9324-x, 2009.

Battin, T. J., Kaplan, L. A., Findlay, S., Hopkinson, C. S., Marti, E., Packman, A. I., Newbold, D. J., and Sabater, F.: Biophysical controls on organic carbon fluxes in fluvial networks, Nat. Geosci., 1, 95-100, doi:10.1038/ngeo101, 2008.

Bernhardt, E. S. and Likens, G. E.: Dissolved organic carbon enrichment alters nitrogen dynamics in a forest stream, Ecology, 83, 1689-1700, 2002.

Bowes, M. J., House, W. A., and Hodgekinson, R. A.: Phosphorus dynamics along a river continuum, Sci. Total Environ., 313, 199 212, doi:10.1016/S0048-9697(03)00260-2, 2003.

Brookshire, E. N. J., Gerber, S., Webster, J. R., Vose, J. M., and Swank, W. T.: Direct effects of temperature on forest nitrogen 
cycling revealed through analysis of long-term watershed records, Glob. Change Biol., 17, 297-308, doi:10.1111/j.13652486.2010.02245.x, 2011.

Butler, S. M., Melillo, J. M., Johnson, J. E., Mohan, J., Steudler, P. A., Lux, H., Burrows, E., Smith, R. M., Vario, C. L., Scott, L., Hill, T. D., Aponte, N., and Bowles, F: Soil warming alters nitrogen cycling in a New England forest: implications for ecosystem function and structure, Oecologia, 168, 819-828, doi:10.1007/s00442-011-2133-7, 2012.

Carrera, J., Vicent, T., and Lafuente, F. J.: Influence of temperature on denitrification of an industrial high-strength nitrogen wastewater in a two-sludge system, Water SA, 29, 11-16, 2003.

Chapin III, F. S., Power, M. E., and Cole, J. J.: Coupled biogeochemical cycles and Earth stewardship, Front. Ecol. Environ., 9, 3-3, doi:10.1890/1540-9295-9.1.3, 2011.

Christ, M. J. and David, M. B.: Temperature and moisture effects on the production of dissolved organic carbon in a Spodosol, Soil Biol. Biochem., 28, 1191-1199, doi:10.1016/00380717(96)00120-4, 1996.

Clément, J., Shrestha, J., Ehrenfeld, J., and Jaffe, P.: Ammonium oxidation coupled to dissimilatory reduction of iron under anaerobic conditions in wetland soils, Soil Biol. Biochem., 37, 23232328, doi:10.1016/j.soilbio.2005.03.027, 2005.

Coble, P. G.: Characterization of marine and terrestrial DOM in seawater using excitation-emission matrix spectroscopy, Mar. Chem., 51, 325-346, 1996.

Daila, D. B. and Fitzgeraldb, J. W.: S Cycling in soil and stream sediment: influence of season and in situ concentrations of carbon, nitrogen and sulfur, Soil Biol. Biochem., 31, 1395-1404, 1999.

Duan, S. W., Amon, R., Bianchi, T. S., and Santschi, P. A.: Temperature Control on Soluble Reactive Phosphorus in the Lower Mississippi River?, Estuaries Coasts, 34, 78-89, 2011.

Duan, S. W., Kaushal, S. S., Groffman, P. M., Band, L. E., and Belt, K. T.: Phosphorus export across an urban to rural gradient in the Chesapeake Bay watershed, J. Geophys. Res.-Biogeo., 117, G01025, doi:10.1029/2011JG001782, 2012.

Fdz-Polanco, F., Villaverde, S., and Garcid, P. A.: Temperature effect on nitrifying bacteria activity in biofilters: activation and free ammonia inhibition, Water Sci. Technol., 30, 121-130, 1994.

Froelich, P. N.: Kinetic control of dissolved phosphate in natural rivers and estuaries - a primer on the phosphate buffer mechanism, Limnol. Oceanogr., 33, 649-668, 1988.

Gilmour, C. C., Henry, E. A., and Mitchell, R.: Sulfate stimulation of mercury methylation in freshwater sediments, Environ. Sci. Technol., 26, 2281-2287, 1992.

Giray, C. and King, G. M.: Effect of naturally occurring bromophenols on sulfate reduction and ammonia oxidation in intertidal sediments, Aquat. Microb. Ecol., 13, 295-301, 1997.

Godfrey, P. and Mitchell, D.: Eutrophication and phosphate detergents, Science, 177, 816-817, doi:10.1126/science.177.4051.816, 1972.

Groffman, P. M., Law, N. L., Belt, K. T., Band, L. E., and Fisher, G. T.: Nitrogen fluxes and retention in urban watershed ecosystems, Ecosystems, 7, 393-403, 2004.

Gudasz, C., Bastviken, D., Steger, K., Premke, K., Sobek, S., and Tranvik, L. J.: Temperature-controlled organic carbon mineralization in lake sediments, Nature, 466, 478-481, doi:10.1038/nature09186, 2010.
House, W. A. and Denison, F. H.: Exchange of inorganic phosphate between river waters and bed-sediments, Environ. Sci. Technol., 36, 4295-4301, doi:10.1021/es020039z, 2002.

Howarth, R., Chan, F., Conley, D. J., Garnier, J., Doney, S. C., Marino, R., and Billen, G.: Coupled biogeochemical cycles: eutrophication and hypoxia in temperate estuaries and coastal marine ecosystems, Front. Ecol. Environ., 9, 18-26, doi:10.1890/100008, 2011.

Hudson, N., Baker, A., and Reynolds, D.: Fluorescence analysis of dissolved organic matter in natural, waste and polluted waters A review, River Res. Appl., 23, 631-649, doi:10.1002/rra.1005, 2007.

Imberger, S. J., Walsh, C. J., and Grace, M. R.: More microbial activity, not abrasive flow or shredder abundance, accelerates breakdown of labile leaf litter in urban streams, J. N. Am. Benthol. Soc., 27, 549-561, doi:10.1899/07-123.1, 2008.

James, W. F. and Barko, J. W.: Diffusive fluxes and equilibrium processes in relation to phosphorus dynamics in the Upper Mississippi River, River Res. Appl., 20, 473-484, 2004.

Javanaud, C., Michotey, V. D., Guasco, S., Garcia, N., Anschutz, P., Canton, M., and Bonin, P. C.: Anaerobic ammonium oxidation mediated by Mn-oxides: from sediment to strain level, Res. Microbiol., 162, 848-857, 2011.

Jensen, H. S. and Anderson, F. O.: Importance of temperature, nitrate, and $\mathrm{pH}$ for phosphate release from aerobic sediments of four shallow eutrophic lakes, Limnol. Oceanogr., 37, 577-589, 1992.

Kaplan, L. A., Wiegner, T. N., Newbold, J. D., Ostrom, P. H., and Gandhi, H.: Untangling the complex issue of dissolved organic carbon uptake: a stable isotope approach, Freshwater Biol., 53, 855-864, doi:10.1111/j.1365-2427.2007.01941.x, 2008.

Kaushal, S. S. and Belt, K. T.: The urban watershed continuum: evolving spatial and temporal dimensions, Urban Ecosystems, 15, 409-435, doi:10.1007/s11252-012-0226-7, 2012.

Kaushal, S. S. and Lewis, W. M.: Fate and transport of organic nitrogen in minimally disturbed montane streams of Colorado, USA, Biogeochemistry, 74, 303-321, doi:10.1007/s10533-0044723-5, 2005.

Kaushal, S. S., Groffman, P. M., Likens, G. E., Belt, K. T., Stack, W. P., Kelly, V .R., Weathers, K. C., Band, L. E., and Fisher, G. T.: Increased salinization of fresh water in the northeastern U.S., P. Natl. Acad. Sci. USA, 102, 13517-13520, 2005.

Kaushal, S. S., Groffman, P. M., Band, L. E., Shields, C. A., Morgan, R. P., Palmer, M. A., Belt, K. T., Fisher, G. T., Swan, C. M., and Findlay, S. E. G.: Interaction between urbanization and climate variability amplifies watershed nitrate export in Maryland, Environ. Sci. Technol., 42, 5872-5878, doi:10.1021/es800264f, 2008a.

Kaushal, S. S., Groffman, P. M., Mayer, P. M., Striz, E., Doheny, E. J., and Gold, A. J.: Effects of stream restoration on denitrification at the riparian-stream interface of an urbanizing watershed of the mid-Atlantic U.S., Ecol. Appl., 18, 789-804, 2008b.

Kaushal, S. S., Likens, G. E., Jaworski, N. A., Pace, M. L., Sides, A. M., Seekell, D., Belt, K. T., Secor, D. H., and Wingate, R. L.: Rising stream and river temperatures in the United States, Front. Ecol. Environ., 8, 461-466, doi:10.1890/090037, 2010.

Kaushal, S. S., Groffman, P. M., Band, L. E., Elliott, E. M., Shields, C. A., and Kendall, C.: Tracking Nonpoint Source Nitrogen Pollution in Human-Impacted Watersheds, Environ. Sci. Technol., 
45, 8225-8232, doi:10.1021/es200779e, 2011.

Kim, H. J.: Temperatures of urban streams: Impervious surface cover, runoff, and the importance of spatial and temporal variations, M.S. thesis, Department of Civil and Environmental Engineering, University of Maryland Baltimore County, USA, 73 pp., 2007.

Lønborg, C., Alvarez-Salgado, X. A., Davidson, K., MartinezGarcia, S., and Teira, E.: Assessing the microbial bioavailability and degradation rate constants of dissolved organic matter by fluorescence spectroscopy in the coastal upwelling system of the Ria de Vigo, Mar. Chem., 119, 121-129, doi:10.1016/j.marchem.2010.02.001, 2010.

Marschner, B. and Bredow, A.: Temperature effects on release and ecologically relevant properties of dissolved organic carbon in sterilised and biologically active soil samples, Soil Biol. Biochem., 34, 459-466, 2002.

Melillo, J. M., Steudler, P. A., Aber, J. D., Newkirk, K., Lux, H., Bowles, F. P., Catricala, C., Magill, A., Ahrens, T., and Morrisseau, S.: Soil warming and carbon-cycle feedbacks to the climate system, Science, 298, 2173-2176, doi:10.1126/science.1074153, 2002.

Melillo, J. M., Butler, S., Johnson, J., Mohan, J., Steudler, P., Lux, H., Burrows, E., Bowles, F., Smith, R., Scott, L., Vario, C., Hill, T., Burton, A., Zhou, Y. M., and Tang, J.: Soil warming, carbon-nitrogen interactions, and forest carbon budgets, P. Natl. Acad. Sci. USA, 108, 9508-9512, doi:10.1073/pnas.1018189108, 2011.

Middelburg, J. J. and Levin, L. A.: Coastal hypoxia and sediment biogeochemistry, Biogeosciences, 6, 1273-1293, doi:10.5194/bg-6-1273-2009, 2009.

Murphy, J. and Riley, J. P.: A modified single solution method for determination of phosphate in natural waters, Anal. Chim. Acta, 26, 31-36, 1962.

Nelson, K. C. and Palmer, M. A.: Stream temperature surges under urbanization and climate change: data, models, and responses, J. Am. Water Resour. As., 43, 440-452, 2007.

Newcomer, T. A., Kaushal, S. S., Mayer, P. M., Shields, A. R., Canuel, E. A., Groffman, P. M., and Gold, A. J.: Influence of natural and novel organic carbon sources on denitrification in forested, degraded-urban, and restored streams, Ecology, 82, 449-466, doi:10.1890/12-0458.1, 2012.

Nguyen, B. T., Lehmann, J., Hockaday, W. C., Joseph, S., and Masiello, C. A.: Temperature sensitivity of black carbon decomposition and oxidation, Environ. Sci. Technol., 44, 3324-3331, doi:10.1021/es903016y, 2010.

O'Driscoll, M., Clinton, S., Jefferson, A., Manda, A., and McMillan, S.: Urbanization Effects on Watershed Hydrology and InStream Processes in the Southern United States, Water, 2, 605648, doi:10.3390/w2030605, 2010.

Pfenning, K. S. and McMahon, P. B.: Effect of nitrate, organic carbon, and temperature on potential denitrification rates in nitraterich riverbed sediments, J. Hydrol., 187, 283-295, 1996.

Saidu, M.-G.: Temperature impact on nitrification and bacterial growth kinetics in acclimating recirculating aquaculture systems biofilters, Ph.D. dissertation, Agricultural and Mechanical College, Louisiana State University, USA, 180 pp., 2009.
Saunders, D. L. and Kalff, J.: Denitrification rates in the sediment of Lake Memphremagog, Canada-USA, Water Res., 35, 18971904, 2001.

Schindler, D. W., Armstrong, F. A. J., Holmgren, S. K., and Brunskill, G. J.: Eutrophication of Lake 227, Experimental Lakes Area, Northwestern Ontario, by addition of phosphate and nitrate, J. Fish Res. Board Can., 28, 1763-1781, 1971.

Schlesinger, W. H., Cole, J. J., Finzi, A. C., and Holland, E. A.: Introduction to coupled biogeochemical cycles, Front. Ecol. Environ., 9, 5-8, doi:10.1890/090235, 2011.

Schulz, M. and Herzog, C.: The influence of sorption processes on the phosphorus mass balance in a eutrophic German lowland river, Water Air Soil Poll., 155, 291-301, 2004.

Seitzinger, S. P.: Denitrification in freshwater and coastal marine ecosystems: Ecological and geochemical significance, Limnol. Oceanogr., 33, 702-724, 1988.

Shields, C. A., Band, L. E., Law, N., Groffman, P. M., Kaushal, S. S., Savvas, K., Fisher, G. T., and Belt, K. T.: Streamflow distribution of non-point source nitrogen export from urban-rural catchments in the Chesapeake Bay watershed, Water Resour. Res., 44, W09416, doi:10.1029/2007WR006360, 2008.

Sivirichi, G. M., Kaushal, S. S., Mayer, P. M., Welty, C., Belt, K. T., Newcomer, T. A., Newcomb, K. D., and Grese, M. M.: Longitudinal variability in streamwater chemistry and carbon and nitrogen fluxes in restored and degraded urban stream networks, J. Environ. Monitor., 13, 288-303, doi:10.1039/c0em00055h, 2011.

Stolpe, B., Guo, L., Shiller, A. M., and Hassellöv, M.: Size and composition of colloidal organic matter and trace elements in the Mississippi River, Pearl River and the northern Gulf of Mexico, as characterized by flow field-flow fractionation, Mar. Chem., 118, 119-128, doi:10.1016/j.marchem.2009.11.007, 2010.

Suplee, M. W. and Cotner, J. B.: An evaluation of the importance of sulfate reduction and temperature to $\mathrm{P}$ fluxes from aerobicsurfaced, lacustrine sediments, Biogeochemistry, 61, 199-228, 2002.

Walker, S. A., Amon, R. M. W., Stedmon, C., Duan, S. W., and Louchouam, P.: The use of PARAFAC modeling to trace terrestrial dissolved organic matter and finger-print water masses in Canadian Arctic surface waters, J. Geophys. Res.-Biogeo., 114, G00F06, doi:10.1029/2009JG000990, 2009.

Webb, B. W. and Nobilis, F.: Long-term changes in river temperature and the influence of climatic and hydrological factors, Hydrolog. Sci. J., 52, 74-85, doi:10.1623/hysj.52.1.74, 2007.

White, P. A., Kalff, J., Rasmussen, J. B., and Gasol, J. M.: The effect of temperature and algal biomass on bacterial production and specific growth-rate in fresh-water and marine habitats, Microb. Eco., 21, 99-118, 1991.

Wilson, K. P. and Williams, D. D.: Response of dissolved organic carbon in a shallow groundwater ecosystem to a simulated global warming experiment, in: Geo-Environment and Landscape Evolution II, Wessex Institute of Technology Press, Southampton, UK, 163-174, 2006.

Zhang, Z. J., Wang, Z. D., Holden, J., Xu, X. H., Wang, H., Ruan, J. H., and $\mathrm{Xu}, \mathrm{X}$.: The release of phosphorus from sediment into water in subtropical wetlands: a warming microcosm experiment, Hydrol. Process., 26, 15-26, doi:10.1002/hyp.8105, 2012. 